\title{
BACTERIAL NANOCELLULOSE MEMBRANES AS POTENTIAL CHRONIC WOUND DRESSING: INFLUENCE OF ALTERNATIVE CULTURE MEDIA ON NANOFIBER DIAMETER - A BRIEF REVIEW ${ }^{1}$
}

\author{
MEMBRANAS DE NANOCELULOSE BACTERIANA COMO POTENCIAL \\ CURATIVO PARA FERIDAS CRÔNICAS: INFLUENCIA DE MEIOS DE CULTURA \\ ALTERNATIVOS NO DIÂMETRO DAS NANOFIBRAS - UMA BREVE REVISÃO
}

\author{
Vinícius Rodrigues Oviedo², Fábio Portela Balbé ${ }^{3}$, Luiz Fernando Rodrigues Jr. ${ }^{3}$, \\ Michele Rorato Sagrillo², Solange Binotto Fagan ${ }^{2}$ and Liana da Silva Fernandes ${ }^{2}$
}

\begin{abstract}
Chronic wounds are a major health problem worldwide. Mainly associated with chronic diseases and aging, this condition decreases life quality and expectancy in patients. Biomaterials are a growing trend in the biomedical industry due to their composition includes substances and similar structures to the human body, what brings the possibility of discovery and use of certain protein bindings and other physiological signs that can aid in the healing and biointegration process. Bacterial nanocellulose is a biomaterial formed by an interlaced fitting of nanofibrils about $100 \mathrm{~nm}$ in diameter, making it an excellent material for chronic wounds dressings due to its specific characteristics, such as (i) liquid absorption capacity, (ii) high crystallinity, (iii) purity, (iv) three-dimensional structure, (vi) permeability to gases and (vii) biocompatibility. To overcome one of its limitations, - the absence of antimicrobial activity - there is the need of structural modifications. These modifications can be in-situ (during the membrane formation) or ex-situ (after the membrane formation), by physical (adsorption or absorption), or chemical (oxidation, esterification, etc.) methods. Another drawback regarding bacterial nanocellulose is the high cost of standard culture media during its production, which has been solved with alternative solutions. This review selected 8 papers in the PubMed and Science Direct databases, in which bacterial nanocellulose was obtained by using alternative media of culture, such as (i) kombucha, (ii) agro-industrial wastes, and (iii) fruit/vegetable peel wastes. The aim of this review is to overview how the production of bacterial nanocellulose in alternative media affects its nanostructure and crystallinity index.
\end{abstract}

Keywords: Nanoscience, biomaterials, fermentation, alternative media, kombucha.

\section{RESUMO}

Feridas crônicas são um dos principais problemas de saúde em todo o mundo, principalmente associadas às doenças crônicas e ao envelhecimento, condição essa que diminui a qualidade e expectativa de vida dos pacientes. Biomateriais são uma tendência crescente na indústria biomédica devido à sua composição incluir substâncias/estruturas semelhantes ao corpo humano, isso traz possibilidade de descoberta e utilização de determinados sítios de ligação de proteinas e sinais fisiológicos que podem auxiliar no processo de cicatrização e biointegração. A nanocelulose bacteriana é um biomaterial constituído pelo entrelaçamento de nanofibrilas (cerca de $100 \mathrm{~nm}$ de diâmetro), tornando-se um excelente material de base para curativos de feridas crônicas devido às características específicas, como (i) capacidade de absorção de líquidos, (ii) elevada cristalinidade, (iii) pureza, (iv) estrutura tridimensional, (vi) permeabilidade a gases e (vii) biocompatibilidade. Para superar 1 Master's work.

2 Nanosciences Post-Graduation Program, Franciscan University (UFN). E-mail: vinicius.oviedo@ufn.edu.br; sagrillomr@ ufn.edu.br; sfagan@ufn.edu.br; liana@ufn.edu.br

3 Biomedical Engineering, Franciscan University (UFN). E-mail: fabio.balbe@ufn.edu.br; luiz.fernando@ufn.edu.br 
uma de suas limitações - ausência de atividade antimicrobiana - são necessárias modificações estruturais. Estas podem ser in-situ (durante a formação da membrana) ou ex-situ (após a formação da membrana), por métodos físicos (adsorção ou absorção) ou químicos (oxidação, esterificação, etc.). Outra desvantagem é o alto custo dos meios de cultura padrão durante sua produção, que vem sendo contornado com soluções alternativas. Esta revisão selecionou 8 artigos nas bases de dados PubMed e Science Direct cuja produção utilizou meios de cultura alternativos, como (i) kombucha, (ii) resíduos agroindustriais e (iii) resíduos de cascas de frutas/vegetais. O objetivo desta revisão é apresentar uma visão geral da influência de meios alternativos sobre a nanoestrutura e o indice de cristalinidade.

Palavras-chave: Nanociências, biomateriais, fermentação, meios alternativos, kombucha.

\section{INTRODUCTION}

The skin is the largest organ of the human body, and it is composed of two distinct layers: the epidermis (external part) and the dermis (internal part). Its major function is the protection of adjacent tissues, in which the skin acts as a mechanical barrier against impacts and humidity loss, besides serving as a chemical barrier that promotes an acidic layer to suppress bacterial growth (BARANOSKI et al., 2016; SUSSMAN; BATES-JENSEN, 2012).

When a lesion occurs, a series of physiological, biochemical, and cellular events happen in order to reestablish both the structural and functional integrity of the target area (KEVIN; VAN DEN KERKHOF; JIMENEZ, 2016; SANTOS et al., 2014). The healing process is a continuous series of events that impose biological changes to the cells to facilitate hemostasis, combat infections, deposit a new extracellular matrix, and promote angiogenesis (HOLLOWAY et al., 2016). The exact mechanisms that lead to an improper wound healing process are not well defined nowadays, however, the two main factors are chronic diseases and aging (KEVIN; VAN DEN KERKHOF; JIMENEZ, 2016). When it takes more than three months for the wound to heal, and the healing process is not ordered, it is defined as a chronic wound (KORTING; SCHÖLLMANN; WHITE, 2011).

Chronic wounds are a worldwide health problem that leads to life quality decrease, to deaths, and expensive costs in healthcare systems (OLSSON et al., 2019). Chronic wounds demand the use of complex wound dressings with a high capacity of exudate retention (UZUN, 2018). Another important characteristic of wound dressings designed for chronic wounds is the antimicrobial activity, once the chronic wounds are very susceptible to bacterial infections, and biofilm formation, two major causes of healing problems (VERBANIC et al., 2020).

Thus, the main roles of wound dressings are: (i) to promote hemostasis, and (ii) to serve as a physical barrier that protects the wound area in a mechanical way. The most common example of traditional wound dressing is cotton gauze (SHERIDAN, 1999). Nevertheless, traditional dressings, in general, show problems when applied to chronic wound treatments, such as: $(i)$ they can damage the epithelium when removed; (ii) they promote superficial dehydration; and (iii) they are not able to 
handle exudate leaking, what increases the probability of infections and bacterial biofilm formation (NAIMER; CHEMLA, 2000; SIRITIENTONG et al., 2014; WEI et al., 2019).

Based on the aforementioned, complex wound dressings should be engineered to promote the following characteristics: (i) humidity control; (ii) low adherence; (iii) protection to mechanical trauma; (iv) low management and simple handling; (v) thermal isolation; (vi) high exudate/blood absorption; (vii) antimicrobial and anti-inflammatory activity; (viii) gaseous exchange promotion; (ix) not be toxic; and $(x)$ be a low-cost product (BROWN-ETRIS; CUTSHALL; HILES, 2002). Moreover, complex wound dressings can be classified into three categories, based on the material characteristic: (i) traditional; (ii) biomaterials-based; and (iii) artificial wound dressings (FREYMAN; YANNAS; GIBSON, 2001; KUS; RUIZ, 2020).

Along with the advances in biomaterials science and nanotechnology, nanostructured wound dressings have been investigated to treat chronic wounds (RATNER et al., 2020; STOICA; CHIRCOV; GRUMEZESCU, 2020). In this sense, a natural biomaterial known as bacterial nanocellulose (BNC) has been explored and used as an alternative dressing for chronic wounds and burns of all degrees of severity (PANG et al., 2020). Also named bacterial cellulose (BC), this exopolysaccharide is chemically composed of cellulose, produced by acetic and non-pathogenic bacteria from a fermentation process that requires oxygen and carbon/nitrogen sources (ABOL-FOTOUH et al., 2020; PORTELA et al., 2019). As these bacteria ferment, a gelatinous biomembrane (located on top) is formed on the culture medium when this culture is static, and suspensions (spherical, pallets, or fibers) when the culture is dynamic (AZEREDO et al., 2019) - the NCB structure and static culture productions are illustrated in Figure 1.

Figure 1 - BNC structure and static culture.
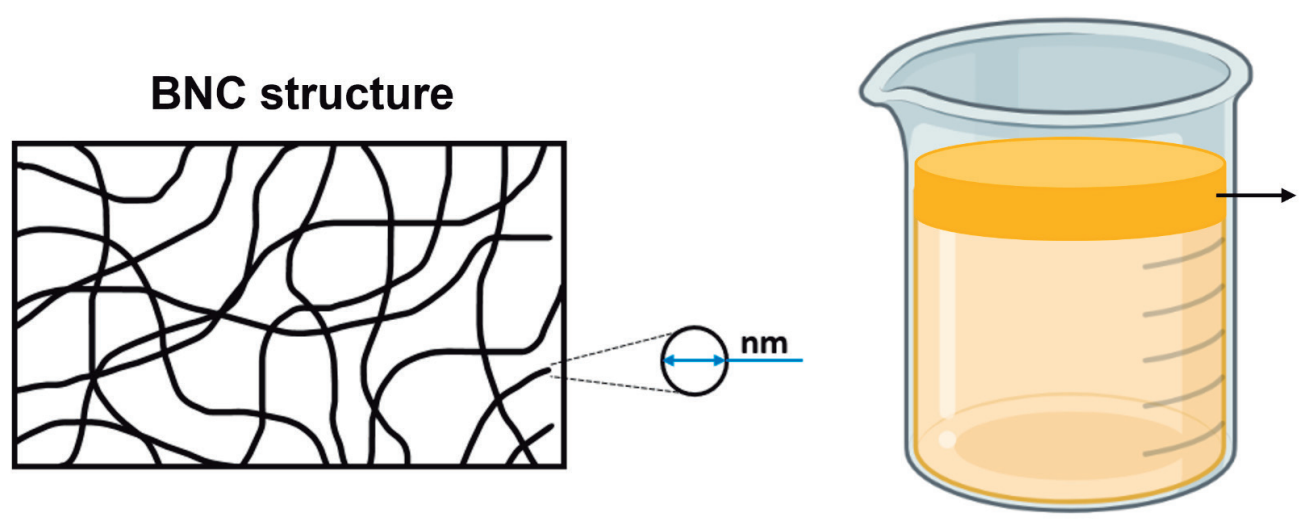

\section{BNC membrane (byproduct)}

\section{Static Culture}

Source: the authors.

It is worthy mentioning that BNC is composed of D-glucose units, linked by $\beta-1,4$ glycosidic bonds. Its structure is formed by a network of random fibrils with about $100 \mathrm{~nm}$ of diameter, what 
results in unique properties, such as: $(i)$ high capacity of exudate absorption; (ii) high-purity (due to the absence of lignin, pectin and hemicellulose phases presented on plant cellulose); (iii) biocompatibility; (iv) tridimensional structure able to mimic the extracellular matrix of native tissues; and (v) permeability to gases (GORGIEVA; TRČEK, 2019). All these properties turn BNC into a promising dressing material for chronic wounds treatment.

Despite the interesting properties of BNC-based wound dressings intended for chronic wounds, it presents two disadvantages. The first one is that it lacks antimicrobial properties in the pristine form, what can be fixed by the addition of antimicrobial agents into its structure (ZHENG et al., 2020). The impregnation methods to solve this problem can be made by in-situ modification (during the culture) or ex-situ modification (after the culture) (STUMPF et al., 2018). The second disadvantage is the scaling-up production, in which the cost of culture media represents $30 \%$ of the total production cost when using standard culture media (JOZALA et al., 2016). The commonly used standard culture medium for BNC production is the Hestrin-Schramm (HS) (COSTA et al., 2017).

In order to overcome problems concerning large-scale BNC production, several approaches have been studied in the literature, such as the use of alternative culture media during static production. Some of these approaches include the use of agroindustrial residues (e.g., sugar cane molasse, beer bagasse, fruit, and plant peel wastes, etc.) as carbon and nitrogen sources (HUSSAIN et al., 2019), while others involve kombucha-like culture media and kombucha fermentation by-products usage (ZHU et al., 2014).

Kombucha-like culture media has been attracting attention of the scientific community (OLIVER-ORTEGA et al., 2021). Kombucha is a fresh and naturally carbonated drink obtained by the fermentation of acetic bacteria and yeasts by using green or black tea (Camellia sinensis) infusions and a sugar source as substrates (VILLARREAL-SOTO et al., 2018). The fermentation process of kombucha occurs through a symbiosis between bacteria and yeast, what also results in a cellulose biomembrane (named SCOBY) as a byproduct on the top of the culture medium (LAAVANYA; SHIRKOLE; BALASUBRAMANIAN, 2021). Several bacteria and yeast were already identified during the fermentation of kombucha and Acetobacter xylinum was found to be the main responsible for kombucha's BNC production, which is also essentially composed of cellulose nanofibers (GORGIEVA; TRČEK, 2019).

Regarding the BNC production by using fruit and agroindustrial wastes as substrates, the process is also based on the fermentation of acetic bacteria, which results in a cellulosic membrane with a protective role on top of the culture medium (MARESTONI et al., 2021). In this sense, the high carbohydrate content of fruit and agroindustrial wastes serves as an important carbon source and leads to a low-cost fermentation media (GÜZEL; AKPINAR, 2020; KADIER et al., 2021).

Despite the alternative approaches for BNC production before mentioned, their influence on the fiber diameter in BNC fibrous network should be addressed to ensure it is at the nanoscale. 
The crystallinity index (CrI), another important and commonly measured property after the purification of BNC, should also be considered as it influences directly into the BNC properties. Then, this review aims at overviewing the influence of alternative culture media during BNC production on nanofiber diameters and crystallinity index.

\section{METHODOLOGY}

The research was carried out in the Science Direct and PubMed databases. Also, the following descriptors were used: "bacterial cellulose", "nano*”, "wound”, "tea”, "fermentation”, "fiber". Based on that, the research papers were selected according to the inclusion and exclusion criteria shown in Figure 2.

Figure 2 - Inclusion/exclusion criteria used in this research.

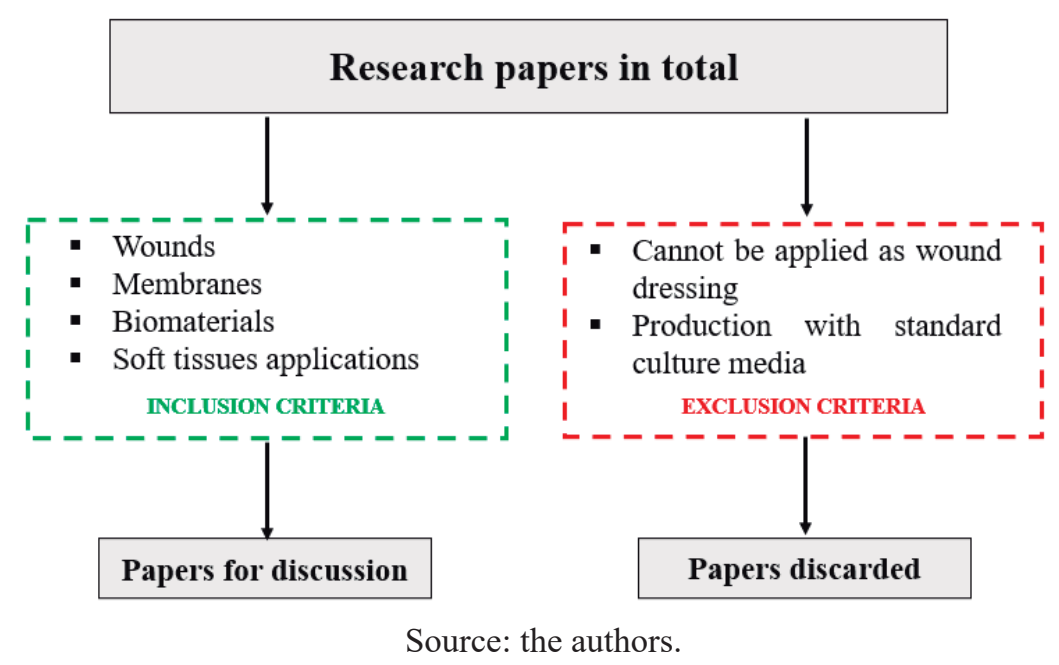

\section{RESULTS AND DISCUSSION}

In total, 20 research papers were found, from which 8 were selected based on the inclusion and exclusion criteria. Additionally, all these papers used alternative culture media to produce BNC. Figure 3 shows the alternative culture media used for BNC production. It is possible to note the predominance of kombucha-like culture media (5 papers, 62.5\%), which 40\% were supplemented with corn syrup (DIMA et al., 2017) or calcium carbonate and yeast extracts (BODEA et al., 2021). Likewise, $25 \%$ (2 papers) of the investigations used agro-industrial wastes, and $12.5 \%$ ( 1 paper) used fruit and vegetable peel wastes as carbon and nitrogen sources for culture media. The predominance of kombucha-like can be associated with the popularity of the drink and the simplicity of the process, what can be compared to a static production of BNC. 
Figure 3 - Alternative culture media used in the selected studies.

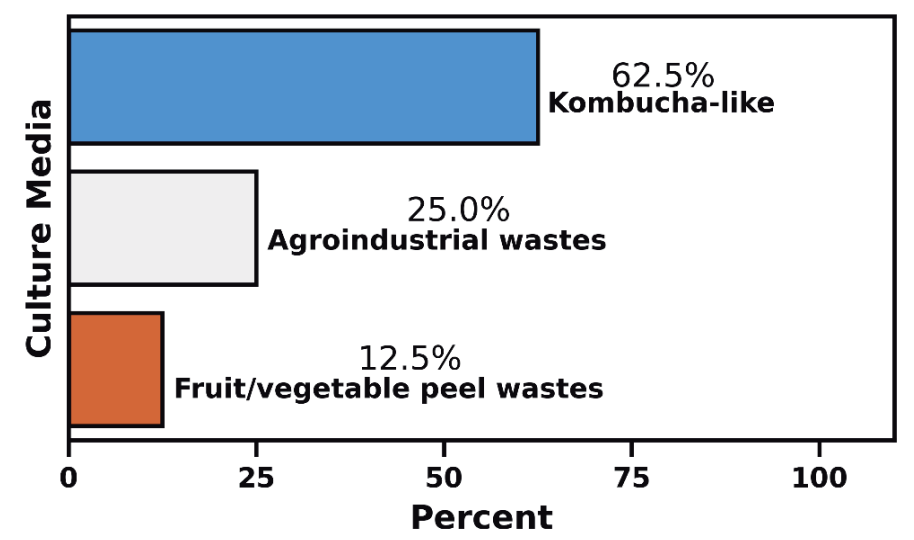

Source: the authors.

The parameters used for BNC production such as culture medium, bacteria strain, inoculum concentration, temperature, and fermentation time are shown in Table 1. As most of the papers did not present the sugar and tea concentration and not all of them included $\mathrm{pH}$ control, this information was omitted from culture parameters. Table 2 shows the results obtained in terms of BNC nanofiber diameters and CrI.

Regarding the bacteria used during BNC production, the most used microorganisms were those included in kombucha SCOBY, as this was the main alternative media used in the investigations. It is known that kombucha SCOBY is usually composed of Acetobacter and Gluconobacter (now renamed as Komagataeibacter) bacteria genus, as well as osmophilic yeasts (LAAVANYA; SHIRKOLE; BALASUBRAMANIAN, 2021; PILLAI et al., 2021). For the other alternative media, the Komagataeibacter genus was the most used due to its wide association with BNC production (REVIN et al., 2021).

Concerning agroindustrial wastes used as fermentation substrates, side-way byproducts from sugar industries, such as sugar beet molasses, can be a low-cost carbon source for BNC production, as its dry matter is formed by about $45-48 \%$ of sucrose (REVIN et al., 2021). In the study by Revin and colleagues (2021), this kind of molasses, which also contain aminoacids, vitamins, minerals, and organic acids, almost doubled the BNC production yield by decreasing the cost of culture medium by about $20 \%$ when compared to HS-derived BNC production (REVIN et al., 2021). In this case, the authors reported NCB production in 5 days, with a higher CrI than HS-derived BNC and a nanofiber diameter between $60-90 \mathrm{~nm}$. 
Table 1 - BNC production parameters using alternative culture media.

\begin{tabular}{|c|c|c|c|c|c|}
\hline Medium & Bacteria & $\begin{array}{c}\text { Inoculum \% } \\
(\mathrm{v} / \mathrm{v})\end{array}$ & $\begin{array}{c}\text { Temperature } \\
\left({ }^{\circ} \mathbf{C}\right)\end{array}$ & $\begin{array}{l}\text { Culture time } \\
\text { (days) }\end{array}$ & Reference \\
\hline Kombucha-like & SCOBY & 10 & - & 14 & Pillai et al., 2021 \\
\hline $\begin{array}{l}\text { Citrus peel and } \\
\text { pomace enzymolysis }\end{array}$ & $\begin{array}{l}\text { Komagataeibacter } \\
\text { xylinus }\end{array}$ & 10 & 30 & 8 & Fan et al., 2016 \\
\hline $\begin{array}{l}\text { Wood hot water extracts } \\
\text { (WHWE) }\end{array}$ & $\begin{array}{c}\text { Acetobacter } \\
\text { xylinum }\end{array}$ & 5 & $26,28,30$ & 10 & $\begin{array}{l}\text { Kiziltas; Kiziltas; } \\
\text { Gardner, } 2015\end{array}$ \\
\hline Sugar beet molasses & $\begin{array}{l}\text { Komagataeibacter } \\
\text { sucrofermentan }\end{array}$ & 10 & 28 & 10 & Revin et al., 2021 \\
\hline Kombucha-like & SCOBY & 6 & 25 & 35 & $\begin{array}{l}\text { Xiang; Acevedo, } \\
2017\end{array}$ \\
\hline Kombucha-like & SCOBY & - & 28 & 15 & Pal et al., 2017 \\
\hline $\begin{array}{l}\text { Kombucha-like supplemented } \\
\text { with corn syrup }\end{array}$ & SCOBY & 10 & 23 & 30 & Dima et al., 2017 \\
\hline $\begin{array}{l}\text { Kombucha-like supplemented } \\
\text { with } \mathrm{CaCO}_{3} \text { and yeast extract }\end{array}$ & $\begin{array}{c}\text { Komagataeibacter } \\
\text { xylinus }\end{array}$ & $1-5$ & 26 & $3,6,9,12,18$ & Bodea et al., 2021 \\
\hline
\end{tabular}

Source: the authors.

Table 2 - Influence of culture medium on fiber diameter and crystallinity index.

\begin{tabular}{|c|c|c|c|c|}
\hline Medium & $\begin{array}{c}\text { Fiber diameter } \\
(\mathrm{nm})\end{array}$ & $\begin{array}{l}\mathrm{CrI} \\
(\%)\end{array}$ & Reference & Comment \\
\hline Kombucha-like & 210 & 67.3 & $\begin{array}{l}\text { Pillai et al., } \\
2021\end{array}$ & $\begin{array}{l}\text { The authors used a kombucha-like culture medium to } \\
\text { decrease the costs of BNC production, focusing on } \\
\text { its processing to be applied as a bioink intended for } \\
\text { 3D printing and tissue engineering. They also used a } \\
\text { SCOBY, weighing } 200 \mathrm{~g} \text {. }\end{array}$ \\
\hline $\begin{array}{l}\text { Citrus peel and } \\
\text { pomace enzymolysis }\end{array}$ & 50 & 63.0 & $\begin{array}{l}\text { Fan et al., } \\
2016\end{array}$ & $\begin{array}{l}\text { The alternative medium served as the carbon and nitro- } \\
\text { gen source. Also, it was compared to HS-derived BNC. It } \\
\text { presented lower crystallinity, but higher production yield. }\end{array}$ \\
\hline $\begin{array}{l}\text { Wood hot water } \\
\text { extracts (WHWE) }\end{array}$ & $15-70$ & 79.0 & $\begin{array}{c}\text { Kiziltas; } \\
\text { Kiziltas; } \\
\text { Gardner, } 2015\end{array}$ & $\begin{array}{l}\text { Low-cost and good yield of BNC production. The } \\
\text { resulting membrane showed slightly lower crystallinity } \\
\text { compared to HS-derived BC. Glucose and xylose were } \\
\text { the nutrients provided by the WHWE. }\end{array}$ \\
\hline Sugar beet molasses & $60-90$ & 83.0 & $\begin{array}{l}\text { Revin et al., } \\
2021\end{array}$ & $\begin{array}{l}\text { The cost of culture media used for production was redu- } \\
\text { ced to } 20 \% \text {. Two-fold BNC production yield (compared } \\
\text { to HS-derived BNC) was obtained. }\end{array}$ \\
\hline Kombucha-like & 59 & 75.5 & $\begin{array}{l}\text { Xiang; } \\
\text { Acevedo, } \\
2017\end{array}$ & $\begin{array}{l}\text { Fermentation occurred at room temperature and started } \\
\text { with } 100 \mathrm{~g} \text { of SCOBY. The authors produced BNC } \\
\text { and BNC/PLA nanocomposites, leading to mechanical } \\
\text { toughness increasing compared to pristine BNC. }\end{array}$ \\
\hline Kombucha-like & $20-40$ & 86.8 & $\begin{array}{l}\text { Pal et al., } \\
2017\end{array}$ & $\begin{array}{l}\text { The authors did not mention the content of starter, sugar, } \\
\text { and tea used during the synthesis. The fibrous structure } \\
\text { was obtained, and BNC presented a great crystallinity. } \\
\text { The researchers also impregnated BNC with Ag nano- } \\
\text { particles, resulting in an antimicrobial wound dressing. }\end{array}$ \\
\hline $\begin{array}{l}\text { Kombucha-like } \\
\text { supplemented with } \\
\text { corn syrup }\end{array}$ & $5-100$ & $87 \%$ & $\begin{array}{l}\text { Dima et al, } \\
2017\end{array}$ & $\begin{array}{l}\text { The sugar source was represented by } 50 \% \text { of fructose, } 44 \% \\
\text { of glucose, and } 6 \% \text { of oligosaccharides. CrI of } 37 \% \text { wi- } \\
\text { thout purification and } 87 \% \text { after purification was achieved. }\end{array}$ \\
\hline $\begin{array}{l}\text { Kombucha-like } \\
\text { supplemented with } \\
\mathrm{CaCO}_{3} \text { and yeast } \\
\text { extract }\end{array}$ & $40.6-51.33$ & - & $\begin{array}{c}\text { Bodea et al., } \\
2021\end{array}$ & $\begin{array}{l}\text { The authors used a Box-Behnken design to optimize the } \\
\text { BNC production. The } \mathrm{CaCO}_{3} \text { addition into the culture } \\
\text { media was not justified. }\end{array}$ \\
\hline
\end{tabular}


Other agroindustrial wastes that can be used during BNC production are wood hot water extracts (WHWE), derived from lignocellulosic industries (ERBAS KIZILTAS; KIZILTAS; GARDNER, 2015). Although WHWE shows a low-composition of sugars, it is a waste material that does not need treatment or supplementation to be applied into BNC production, turning it into a low-cost alternative that results in a slight lesser CrI when compared to BNC produced by using HS medium (ERBAS KIZILTAS; KIZILTAS; GARDNER, 2015). The study of Kiziltas and colleagues (2015) confirmed similarities between structures of HS- and WHWE-derived BNC, with nanofiber diameter (ranging 15-70 nm) slightly lesser than HS-derived BNC.

Similarly, fruit/vegetable peel wastes were also used as carbon/nitrogen sources during the BNC production. Citrus peel and pomace enzymolysis were used as alternative culture media in the Fan and collaborators' work and this resulted in a BNC yield 1.46 higher than HS-derived BNC (FAN et al., 2016). The methodology implicated in CrI decreasing ( $\mathrm{CrI}=63 \%$ against $65 \%$ of HS culture medium) and in a smaller average diameter of the BNC nanofibers (50 nm against $60 \mathrm{~nm}$ of control BNC) (FAN et al., 2016). Furthermore, kombucha-like media or media that reuses kombucha byproducts can also be used for BNC production. The kombucha fermentation process is relatively simple as it only needs green or black tea, a solution containing bacteria and yeast from a previous process (commonly called starter), and the BNC membrane is naturally formed during fermentation (PAL et al., 2017). In the study of Pal and collaborators (2017), it was possible to obtain the BNC membrane in 15 days and the fermentation broth could be used as the new starter solution. The authors achieved a $\mathrm{CrI}$ of $86.8 \%$ after purification of the obtained membranes, which presented outstanding nanofiber diameters $(20-40 \mathrm{~nm})$.

In addition, when kombucha is used as the culture medium for BNC production, a SCOBY can also be used and this trends to assist the fermentation (XIANG; ACEVEDO, 2017). In the work of Xiang and colleagues, a larger and unusual time of fermentation of 5 weeks was evaluated, what leads to a $59 \pm 17 \mathrm{~nm}$ average nanofiber diameter. Also, the CrI was found to be $75.5 \% \pm 2.5 \%$ (XIANG; ACEVEDO, 2017). In this sense, Pillai and collaborators also used a SCOBY during the fermentation process and noted different swelling properties for wet and dry NCB membranes, which is an important property for wound dressings (PILLAI et al., 2021).

As previously mentioned, supplemented kombucha-like culture media was also investigated in the literature. Dima and colleagues supplemented the culture media with corn syrup due to its composition of fructose (50\% of dry matter), glucose (44\% of dry matter), and oligosaccharides ( $6 \%$ of dry matter), what makes it an interesting source for carbon during a longer fermentation time to obtain a kombucha vinegar (DIMA et al., 2017). The authors obtained CrI up to $87.0 \%$ and nanofiber diameters in the range of 5-100 nm, respectively. Similarly, Bodea and collaborators (2021) supplemented the kombucha-like medium with calcium carbonate, despite the reason was not informed in their paper. It was found that the inoculum and fermentation time did not influence the homogeneity 
of obtained BNC membranes, as well as a two-step effective purification process for BNC (BODEA et al., 2021). Also, nanofibers' average diameter was between 40.6-51.33 nm and the CrI was, unfortunately, not measured.

Despite the possibility of obtaining a BNC membrane in 8 days (FAN et al., 2016), most of the studies focused on larger fermentation times, relying on 10-30 days (fermentation parameters are shown in Table 1). Concerning temperature, the range of $23-30{ }^{\circ} \mathrm{C}$ seemed to be suitable for BNC production.

According to Table 2, it can be seen that CrI values were high overall, as expected for BNC. It is interesting to point out that the $\mathrm{CrI}$ is often calculated by X-ray diffraction (XRD) by using Equation (1) and it is directly related to BNC properties (REVIN et al., 2021). Additionally, the culture medium and fermentation parameters such as those listed in Table 1 can influence the CrI of the produced BNC membranes.

$$
\operatorname{CrI}(\%)=\frac{I_{(002)}-I_{\text {amorphous }}}{I_{(002)}} \times 100
$$

Where:

$I_{(002)}:$ maximum intensity of the peak related to the (002) diffraction plane;

$\mathrm{I}_{\text {amorphous }}$ : minimum intensity of the amorphous area between the two characteristic peaks of NCB diffractogram.

It is also important to mention that the nanofiber diameters of BNC were mainly determined by microscopic images, and they were commonly represented as a range - as can be seen in Table 2 . It is also worthy pointing out that the nanofiber diameter was generally less than $100 \mathrm{~nm}$, with the study of Pillai and colleagues as the exception (PILLAI et al., 2021). In this study, larger nanofiber diameters were obtained (up to $290 \mathrm{~nm}$ ) and such values were assigned to the culture of BNC by a planar geometry, which results in anisotropy of the resulting material during static cultivation (PILLAI et al., 2021).

Moreover, to optimize the BNC production, some statistical methods such as Design of Experiments (DOE) can also be used, and these methods can positively affect BNC properties, resulting in reproducible nanofiber diameters and CrI (BODEA et al., 2021; ERBAS KIZILTAS; KIZILTAS; GARDNER, 2015). Based on that, CrI and nanofiber diameter might be used as response variables in addition to $\mathrm{BNC}$ production yield.

\section{CONCLUSION}

On account of the economic and social impact of chronic wounds worldwide, aligning nanoscience and biomaterials can lead to alternatives to this issue. This said, BNC is a biopolymer 
that displays unique properties due to its nanosized structure. The tridimensional and nanofibrillar morphology of NCB turned it into an interesting and potential dressing intended for chronic wounds. However, the high cost of standard culture media, such as HS medium, is a drawback for BNC scaleup production. To overcome this, several alternative culture media have been investigated by using kombucha byproducts, agroindustrial residues, and fruit/vegetable peel wastes. Despite the advances in alternative BNC production, it is important to confirm the nanosized fiber diameter and high CrI, which ensures the unique properties of BNC. It was concluded that the use of alternative culture media maintained the nanosized fiber diameters of BNC and these diameters were majorly found to be less than $100 \mathrm{~nm}$. Nevertheless, the use of alternative culture media led to variations in BNC nanofiber diameters, while the CrI continued high when compared to BNC produced by conventional methods. Thus, as the fibrous network of BNC remained at the nanoscale, the unique properties of this kind of cellulose are maintained. In addition, these results justify the use of alternative culture media as an economic way to obtain nanofibrous BNC membranes. Yet, further studies involving robust statistical methods, such as DOE, could be done to decrease the variability of the resulting nanofiber diameters when using alternative culture media for BNC production.

\section{REFERENCES}

ABOL-FOTOUH, D.; HASSAN, M. A.; SHOKRY, H.; ROIG, A.; AZAB, M. S.; KASHYOUT, A. E. H. B. Bacterial nanocellulose from agro-industrial wastes: low-cost and enhanced production by Komagataeibacter saccharivorans MD1. Scientific Reports, v. 10, n. 1, p. 1-14, 2020.

AZEREDO, H. M. C.; BARUD, H.; FARINAS, C. S.; VASCONCELLOS, V. M.; CLARO, A. M. Bacterial Cellulose as a Raw Material for Food and Food Packaging Applications. Frontiers in Sustainable Food Systems, v. 3, p. 1-14, 2019.

BARANOSKI, S.; AYELLO, E. A.; LEVINE, J. M.; LEBLANC, K.; TOMIC-CANIC, M. Skin: An Essential Organ. In: BARANOSKI, S.; AYELLO, E. A. (org.). Wound care essentials: practice principles. 4. ed. Philadelphia: Wolters Kluwer, 2016. p. 117-175.

BODEA, I. M.; BETEG, F. I.; POP, C. R.; DAVID, A. P.; DUDESCU, M. C.; VILĂU, C.; STĂNILĂ, A.; ROTAR, A. M.; CĂTUNESCU, G. M. Optimization of Moist and Oven-Dried Bacterial Cellulose Production for Functional Properties. Polymers, v. 13, n. 13, p. 1-25, 2021.

BROWN-ETRIS, M.; CUTSHALL, W. D.; HILES, M. C. A new biomaterial derived from small intestine submucosa and developed into a wound matrix device. Wounds, v. 14, n. 4, p. 150-166, 2002. 
COSTA, A. F. S.; ALMEIDA, F. C. G.; VINHAS, G. M.; SARUBBO, L. A. Production of Bacterial Cellulose by Gluconacetobacter hansenii Using Corn Steep Liquor As Nutrient Sources. Frontiers in Microbiology, v. 8, n. OCT, p. 1-12, 2017.

DIMA, S.-O. et al. Bacterial Nanocellulose from Side-Streams of Kombucha Beverages Production: Preparation and Physical-Chemical Properties. Polymers, v. 9, n. 12, p. 1-24, 2017.

ERBAS KIZILTAS, E.; KIZILTAS, A.; GARDNER, D. J. Synthesis of bacterial cellulose using hot water extracted wood sugars. Carbohydrate Polymers, v. 124, p. 131-138, 2015.

FAN, X.; GAO, Y.; HE, W.; HU, H.; TIAN, M.; WANG, K.; PAN, S. Production of nano bacterial cellulose from beverage industrial waste of citrus peel and pomace using Komagataeibacter xylinus. Carbohydrate Polymers, v. 151, p. 1068-1072, 2016.

FREYMAN, T. M.; YANNAS, I. V.; GIBSON, L. J. Cellular materials as porous scaffolds for tissue engineering. Progress in Materials Science, v. 46, n. 3-4, p. 273-282, 2001.

GORGIEVA; TRČEK. Bacterial Cellulose: Production, Modification and Perspectives in Biomedical Applications. Nanomaterials, v. 9, n. 10, p. 1-20, 2019.

GÜZEL, M.; AKPINAR, Ö. Preparation and characterization of bacterial cellulose produced from fruit and vegetable peels by Komagataeibacter hansenii GA2016. International Journal of Biological Macromolecules, v. 162, p. 1597-1604, 2020.

HOLLOWAY, S.; HARDING, K.; STECHMILLER, J. K.; SCHULTZ, G. Acute and Chronic Wound Healing. In: BARANOSKI, S.; AYELLO, E. A. (org.). Wound care essentials: practice principles. 4. ed. Philadelphia: Wolters Kluwer, 2016. p. 176-205.

HUSSAIN, Z.; SAJJAD, W.; KHAN, T.; WAHID, F. Production of bacterial cellulose from industrial wastes: a review. Cellulose, v. 26, n. 5, p. 2895-2911, 2019.

JOZALA, A. F.; DE LENCASTRE-NOVAES, L. C.; LOPES, A. M.; DE CARVALHO SANTOS-EBINUMA, V.; MAZZOLA, P. G.; PESSOA-JR, A.; GROTTO, D.; GERENUTTI, M.; CHAUD, M. V. Bacterial nanocellulose production and application: a 10-year overview. Applied Microbiology and Biotechnology, v. 100, n. 5, p. 2063-2072, 2016. 
KADIER, A. et al. Use of Industrial Wastes as Sustainable Nutrient Sources for Bacterial Cellulose (BC) Production: Mechanism, Advances, and Future Perspectives. Polymers 2021, v. 13, n. 19, p. $1-47,2021$

KEVIN, Y. W.; VAN DEN KERKHOF, E.; JIMENEZ, C. Quality of life and Chronic Wound Care. In: BARANOSKI, S.; AYELLO, E. A. (org.). Wound care essentials: practice principles. 4. ed. Philadelphia: Wolters Kluwer, 2016. p. 26-48.

KORTING, H.; SCHÖLLMANN, C.; WHITE, R. Management of minor acute cutaneous wounds: importance of wound healing in a moist environment. Journal of the European Academy of Dermatology and Venereology, v. 25, n. 2, p. 130-137, 2011.

KUS, K. J. B.; RUIZ, E. S. Wound Dressings - A Practical Review. Current Dermatology Reports, v. 9 , n. 4 , p. 298-308, 2020.

LAAVANYA, D.; SHIRKOLE, S.; BALASUBRAMANIAN, P. Current challenges, applications and future perspectives of SCOBY cellulose of Kombucha fermentation. Journal of Cleaner Production, v. 295, p. 1-20, 2021.

MARESTONI, L. D.; BARUD, H. da S.; GOMES, R. J.; CATARINO, R. P. F.; HATA, N. N. Y.; RESSUTTE, J. B.; SPINOSA, W. A. Commercial and potential applications of bacterial cellulose in Brazil: ten years review. Polímeros, v. 30, n. 4, p. 1-19, 2021.

NAIMER, S. A.; CHEMLA, F. Elastic adhesive dressing treatment of bleeding wounds in trauma victims. The American Journal of Emergency Medicine, v. 18, n. 7, p. 816-819, 2000.

OLIVER-ORTEGA, H.; GENG, S.; ESPINACH, F. X.; OKSMAN, K.; VILASECA, F. Bacterial Cellulose Network from Kombucha Fermentation Impregnated with Emulsion-Polymerized Poly(methyl methacrylate) to Form Nanocomposite. Polymers, v. 13, n. 4, p. 1-17, 2021.

OLSSON, M.; JÄRBRINK, K.; DIVAKAR, U.; BAJPAI, R.; UPTON, Z.; SCHMIDTCHEN, A.; CAR, J. The humanistic and economic burden of chronic wounds: A systematic review. Wound Repair and Regeneration, v. 27, n. 1, p. 114-125, 2019.

PAL, S.; NISI, R.; STOPPA, M.; LICCIULLI, A. Silver-Functionalized Bacterial Cellulose as Antibacterial Membrane for Wound-Healing Applications. ACS Omega, v. 2, n. 7, p. 3632-3639, 2017. 
PANG, M. et al. Application of bacterial cellulose in skin and bone tissue engineering. European Polymer Journal, v. 122, p. 1-30, 2020.

PILLAI, M. M.; TRAN, H. N.; SATHISHKUMAR, G.; MANIMEKALAI, K.; YOON, J.; LIM, D.; NOH, I.; BHATTACHARYYA, A. Symbiotic culture of nanocellulose pellicle: A potential matrix for 3D bioprinting. Materials Science and Engineering: C, v. 119, n. June 2020, p. 1-8, 2021.

PORTELA, R.; LEAL, C. R.; ALMEIDA, P. L.; SOBRAL, R. G. Bacterial cellulose: a versatile biopolymer for wound dressing applications. Microbial Biotechnology, v. 12, n. 4, p. 586-610, 2019.

RATNER, B. D.; HOFFMAN, A. S.; SCHOEN, F. J.; LEMONS, J. E.; WAGNER, W. R.; SAKIYAMA-ELBERT, S. E.; ZHANG, G.; YASZEMSKI, M. J. Introduction to Biomaterials Science. In: Biomaterials Science. Amsterdam: Elsevier, 2020. p. 3-19.

REVIN, V. V.; DOLGANOV, A. V.; LIYASKINA, E. V.; NAZAROVA, N. B.; BALANDINA, A. V.; DEVYATAEVA, A. A.; REVIN, V. D. Characterizing Bacterial Cellulose Produced by Komagataeibacter sucrofermentans H-110 on Molasses Medium and Obtaining a Biocomposite Based on It for the Adsorption of Fluoride. Polymers, v. 13, n. 9, p. 1-16, 2021.

SANTOS, I. C. R. V.; SOUZA, M. A. D. O.; ANDRADE, L. N. V. de; LOPES, M. P.; BARROS E SILVA, M. F. A. de; SANTIAGO, R. T. Characterization of care for patients with wounds in Primary Care. Revista da Rede de Enfermagem do Nordeste, v. 15, n. 4, p. 613-620, 2014.

SHERIDAN, R. Skin Substitutes in Burns. Burns, v. 25, n. 2, p. 97-103, 1999.

SIRITIENTONG, T.; ANGSPATT, A.; RATANAVARAPORN, J.; ARAMWIT, P. Clinical Potential of a Silk Sericin-Releasing Bioactive Wound Dressing for the Treatment of Split-Thickness Skin Graft Donor Sites. Pharmaceutical Research, v. 31, n. 1, p. 104-116, 2014.

STOICA, A. E.; CHIRCOV, C.; GRUMEZESCU, A. M. Nanomaterials for wound dressings: An Up-to-Date overview. Molecules, v. 25, n. 11, p. 1-25, 2020.

STUMPF, T. R.; YANG, X.; ZHANG, J.; CAO, X. In situ and ex situ modifications of bacterial cellulose for applications in tissue engineering. Materials Science and Engineering: C, v. 82, p. 372-383, 2018. 
SUSSMAN, C.; BATES-JENSEN, B. M. Skin and Soft Tissue Anatomy and Wound Healing Physiology. In: SUSSMAN, C.; BATES-JENSEN, B. M. (org.). Wound care a collaborative practice manual for health professionals. 4. ed. Philadelphia: Wolters Kluwer| Lippincott Williams \& Wilkins, 2012. p. 17-52.

UZUN, M. A review of wound management materials. Journal of Textile Engineering \& Fashion Technology, v. 4, n. 1, p. 53-59, 2018.

VERBANIC, S.; SHEN, Y.; LEE, J.; DEACON, J. M.; CHEN, I. A. Microbial predictors of healing and short-term effect of debridement on the microbiome of chronic wounds. NPJ Biofilms and Microbiomes, v. 6, n. 1, p. 1-11, 2020.

VILLARREAL-SOTO, S. A.; BEAUFORT, S.; BOUAJILA, J.; SOUCHARD, J.-P.; TAILLANDIER, P. Understanding Kombucha Tea Fermentation: A Review. Journal of Food Science, v. 83, n. 3, p. 580-588, 2018.

WEI, D.; ZHU, X.-M.; CHEN, Y.-Y.; LI, X.-Y.; CHEN, Y.-P.; LIU, H.-Y.; ZHANG, M. Chronic wound biofilms. Chinese Medical Journal, v. 132, n. 22, p. 2737-2744, 2019.

XIANG, C.; ACEVEDO, N. In Situ Self-Assembled Nanocomposites from Bacterial Cellulose Reinforced with Eletrospun Poly(lactic acid)/Lipids Nanofibers. Polymers, v. 9, n. 12, p. 1-13, 2017.

ZHENG, L.; LI, S.; LUO, J.; WANG, X. Latest Advances on Bacterial Cellulose-Based Antibacterial Materials as Wound Dressings. Frontiers in Bioengineering and Biotechnology, v. 8, p. 1-15, 2020.

ZHU, C.; LI, F.; ZHOU, X.; LIN, L.; ZHANG, T. Kombucha-synthesized bacterial cellulose: Preparation, characterization, and biocompatibility evaluation. Journal of Biomedical Materials Research Part A, v. 102, n. 5, p. 1548-1557, 2014. 